\title{
Kandydat do nowej terapii niewydolności serca z obniżoną frakcją wyrzutową - ARNI (angiotensin receptor-nephrilysin inhibitor). Przewodnik klinicysty
}

\author{
Candidate for new heart failure and reduced ejection fraction therapy \\ - angiotensin receptor-neprilysin inhibitor (ARNI). Clinician's guide
}

\author{
Anna Chuda, Małgorzata Lelonek \\ Zakład Kardiologii Nieinwazyjnej Uniwersytetu Medycznego w Łodzi
}

\section{Streszczenie}

Europejskie Towarzystwo Kardiologiczne w ostatnio opublikowanych w 2016 roku wytycznych dotyczących niewydolności serca (HF) wprowadziło do terapii pacjentów z niewydolnością serca i obniżoną frakcją wyrzutową (HFrEF) nową grupę leków - ARNI (angiotensin receptor-nephrilysin inhibitor) (klasa I zaleceń, poziom dowodów B). Jedynym przedstawicielem ARNI jest sakubitryl/walsartan. Na podstawie wyników badania PARADAGIM-HF sakubitryl/walsartan jest zalecany zamiast inhibitorów konwertazy angiotensyny (ACE) do dalszego obniżenia ryzyka zgonu i hospitalizacji z powodu HF u ambulatoryjnych chorych ze stabilną HFrEF, u których objawy HF (II-IV klasy wg New York Heart Association) utrzymują się mimo optymalnego leczenia inhibitorem ACE (lub antagonistą receptora dla angiotensyny II), beta-adrenolitykiem i antagonistą receptora mineralokortykoidowego. W pracy zaprezentowano opis pierwszych 2 pacjentów z HFrEF, u których zainicjowano terapię lekiem sakubitryl/walsartan.

Słowa kluczowe: niewydolność serca z obniżoną frakcją wyrzutową, antagonista receptora dla angiotensyny II i inhibitor neprylizyny, ARNI

Folia Cardiologica 2017; 12, 4: 397-404

\section{Wstęp}

W Polsce na niewydolność serca (HF, heart failure) choruje 600-700 tys. pacjentów [1]. Populacja chorych z HF systematycznie się powiększa. Należy pamiętać, że skuteczne leczenie HF oraz zapobieganie postępowi choroby jest możliwe. Warunkiem pozostaje między innymi optymalizacja leczenia zgodnie z wytycznymi, w tym sprawne wdrażanie nowych innowacyjnych leków, takich jak sakubitryl/ /walsartan.

Europejskie Towarzystwo Kardiologiczne (ESC, European Society of Cardiology) w 2016 roku opublikowało nowe wytyczne dotyczące HF [2]. W dokumencie tym po raz pierwszy do terapii niewydolności serca z obniżoną frakcją wyrzutową (HFrEF, heart failure reduced ejection fraction) wprowadzono nową grupę leków - ARNI. Jedynym przedstawicielem ARNI jest sakubitryl/walsartan. Molekuła ta zawiera dwie substancje, sakubitryl i walsartan. Aktywny metabolit proleku sakubitrylu, LBQ657, wykazuje działanie hamujące enzym neprylizynę, a walsartan jednoczasowo blokuje działania angiotensyny II. Neprylizyna jest enzymem proteolitycznym z grupy metaloproteaz, który rozkłada i unieczynnia peptydy wazoaktywne, między innymi peptydy natriuretyczne. Hamowanie neprylizyny przez LBQ657 powoduje zwiększenie dostępności peptydów natriuretycznych [3]. Korzystnymi tego klinicznymi efektami w HF są: zwiększenie diurezy, zwiększenie wydalania sodu z moczem, rozszerzenie naczyń krwionośnych, zwiększenie wskaźnika przesączania kłębuszkowego i przepływu krwi przez nerki, zahamowanie uwalniania reniny i aldosteronu, 


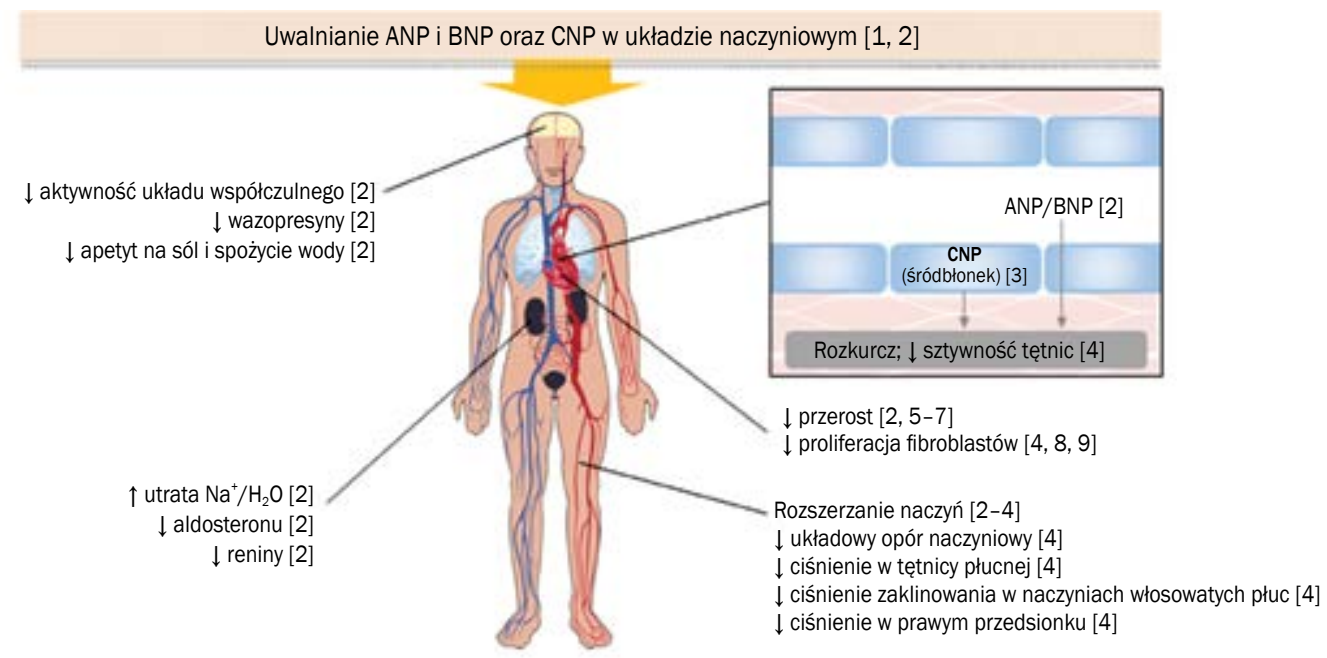

Rycina 1. Peptydy natriuretyczne - potencjalnie korzystne działanie na przebieg niewydolności serca (przygotowano na podstawie [1-9*]); ANP (atrial natriuretic peptide) - przedsionkowy peptyd natriuretyczny; BNP (B-type natriuretic peptide) - peptyd natriuretyczny typu B; CNP (C-type natriuretic peptide) - peptyd natriuretyczny typu; HF (heart failure) - niewydolność serca; *1. Mangiafico i wsp. Eur Heart J. 2013; 2. Levin i wsp. N. Engl. J. Med. 1998; 3. Lumsden i wsp. Curr. Pharm. Des. 2010; 4. Langenickel, Dole. Drug Discovery Today: Ther. Strateg. 2012; 5. Gardner i wsp. Hypertension 2007; 6. Tokudome i wsp. Circulation 2008; 117; 2329-2339; 7. Horio i wsp. Hypertension 2000; 8. D'Souza i wsp. Pharmacol. Ther. 2004; 9. Cao i Gardner. Hypertension 1995

zmniejszenie aktywności układu współczulnego, hamowanie niekorzystnego remodelingu mięśnia sercowego (aktywacji wzrostu i proliferacji komórek, a w konsekwencji przerostu i włóknienia) [3-5] (ryc. 1). Połączenie sakubitryl/ walsartan (produkt leczniczy Entresto ${ }^{T M}$ ) jest pierwszym dostępnym na rynku preparatem z grupy selektywnych antagonistów receptora $\mathrm{AT}_{1}$ dla angiotensyny II (ARB, angiotensin receptor blocker) (walsartan) i inhibitorów neprylizyny (sakubitryl) [3,4]. Sakubitryl jako lek prosty nie jest dostępny na rynku lekowym - stosuje się go jedynie w połączeniu z walsartanem [6].

\section{Opis leku sakubitryl/walsartan}

\section{i wyników badania PARADIGM-HF}

Skuteczność kliniczną leku sakubitryl/walsartan (wcześniejsza nazwa LCZ696) w leczeniu objawowej przewlekłej HFrEF udokumentowano w badaniu PARADIGM-HF (Prospective comparison of ARNI with ACEI to Determine Impact on Global Mortality and morbidity in Heart Failure) - wieloośrodkowym, randomizowanym badaniu klinicznym III fazy, służącym ocenie długoterminowej skuteczności i bezpieczeństwa terapii za pomocą LCZ696 w porównaniu z enalaprilem [7]. Badanie przeprowadzono z udziałem rekordowej liczby 8399 objawowych pacjentów (II-IV klasa wg New York Heart Association [NYHA]), z przewlekłą HF z EF nieprzekraczającą 40\% (zmiana na $\leq 35 \%$ od grudnia 2010 r.), poddanych pełnemu, tolerowanemu, zgodnemu z aktualnymi zaleceniami leczeniu HF. Badanie zakończono wcześniej niż zaplanowano ze względu na istotne korzyści, jakie odnosili chorzy w grupie leczonej LCZ696 w porównaniu z grupą leczoną enalaprilem. W okresie obserwacji (mediana 27 miesięcy), w porównaniu z enalaprilem, LCZ696 obniżył o 20\% ryzyko wystąpienia pierwszorzędowego punktu końcowego (złożony punkt końcowy uwzględniający zgon z przyczyn sercowo-naczyniowych lub pierwszą hospitalizację z powodu HF) oraz ryzyko zgonu z przyczyn sercowo-naczyniowych o $20 \%$ i ryzyko hospitalizacji z powodu HF o 21\%. W zakresie drugorzędowych punktów końcowych istotną przewagę również uzyskała terapia LCZ696 prowadząca do obniżenia o 16\% ryzyka zgonu z jakiejkolwiek przyczyny [3, 7]. Szczegółowe wyniki badania PARADIGM-HF przedstawiono w tabeli 1.

Na podstawie wyników badania PARADIGM-HF Europejska Agencja Leków (EMA, European Medicines Agency) i amerykańska Agencja ds. Żywności i Leków (FDA, Food and Drug Administration) zatwierdziły w 2015 roku stosowanie sakubitrylu/walsartanu w leczeniu pacjentów z objawową przewlekłą HFrEF [8]. Następnie ESC w wytycznych dotyczących HF, opublikowanych pod koniec maja 2016 roku, przyznało klasę l i poziom dowodów B zaleceniu stosowania sakubitrylu/walsartanu zamiast inhibitora ACE w celu dalszego obniżania ryzyka zgonu i hospitalizacji z powodu HF u ambulatoryjnych chorych ze stabilną HF i udokumentowaną frakcją wyrzutową lewej komory (LVEF, left ventricular ejection fraction) nie większą niż $35 \%$, u których objawy w II-IV klasie według NYHA utrzymują się mimo optymalnego leczenia inhibitorem ACE (lub ARB), beta-adrenolitykiem i antagonistą receptora mineralokortykoidowego (MRA, mineralocorticoid receptor antagonist) [2, 8]. Warunkiem zastosowania tego leku 
Tabela 1. Pierwszorzędowe i drugorzędowe punkty końcowe w badaniu PARADIGM-HF (Prospective comparison of ARNI with ACEI to Determine Impact on Global Mortality and morbidity in Heart Failure) (źródło [7])

\begin{tabular}{|c|c|c|c|c|}
\hline Punkt końcowy & $\begin{array}{l}\text { LCZ696 } \\
(n=4187)\end{array}$ & $\begin{array}{l}\text { Enalapril } \\
(\mathrm{n}=4212)\end{array}$ & $\begin{array}{c}\text { Współczynnik ryzyka } \\
(95 \% \mathrm{Cl})\end{array}$ & Wartość p \\
\hline \multicolumn{5}{|l|}{ Pierwszorzędowy punkt końcowy } \\
\hline $\begin{array}{l}\text { Zgon z przyczyn sercowo-naczyniowych } \\
\text { lub pierwsza hospitalizacja z powodu HF }\end{array}$ & $\begin{array}{c}914 \\
(21,8)\end{array}$ & $\begin{array}{l}1117 \\
(26,5)\end{array}$ & $\begin{array}{c}0,80 \\
(0,73-0,87)\end{array}$ & $<0,001$ \\
\hline Zgon z przyczyn sercowo-naczyniowych & $\begin{array}{c}558 \\
(13,3)\end{array}$ & $\begin{array}{c}693 \\
(16,5)\end{array}$ & $\begin{array}{c}0,80 \\
(0,71-0,89)\end{array}$ & $<0,001$ \\
\hline Pierwsza hospitalizacja z powodu HF & $\begin{array}{c}537 \\
(12,8)\end{array}$ & $\begin{array}{c}658 \\
(15,6)\end{array}$ & $\begin{array}{c}0,79 \\
(0,71-0,89)\end{array}$ & $<0,001$ \\
\hline \multicolumn{5}{|l|}{ Drugorzędowy punkt końcowy } \\
\hline Zgon z jakiejkolwiek przyczyny & $\begin{array}{c}711 \\
(17,0)\end{array}$ & $\begin{array}{c}835 \\
(19,8)\end{array}$ & $\begin{array}{c}0,84 \\
(0,76-0,93)\end{array}$ & $<0,001$ \\
\hline Zmiana w KCCQ1 w 8. miesiącu badania & $-2,99 \pm 0,36$ & $-4,63 \pm 0,36$ & $\begin{array}{c}1,64 \\
(0,63-2,65)\end{array}$ & 0,001 \\
\hline Wystąpienie migotania przedsionków² & $\begin{array}{c}84 \\
(3,1)\end{array}$ & $\begin{array}{c}83 \\
(3,1)\end{array}$ & $\begin{array}{c}0,97 \\
(0,72-1,31)\end{array}$ & 0,83 \\
\hline Pogorszenie funkcji nerek & $\begin{array}{c}94 \\
(2,2)\end{array}$ & $\begin{array}{l}108 \\
(2,6)\end{array}$ & $\begin{array}{c}0,86 \\
(0,65-1,13)\end{array}$ & 0,28 \\
\hline
\end{tabular}

${ }^{1}$ Kansas City Cardiomyopathy Questionnaire (KCCQ) obejmuje zakres 0-100 pkt.; wysokie wyniki świadczą o mniejszym nasileniu objawów HF; ${ }^{2}$ całkowita liczba 2670 pacjentów w grupie stosującej LZC696; 2638 pacjentów w grupie stosującej enalapril, u których migotania przedsionków nie stwierdzono $w$ trakcie wizyty randomizacyjnej, było ocenianych pod względem możliwości wystąpienia migotania przedsionków podczas badania; HF (heart failure) - niewydolność serca

jest tolerancja dotychczasowego leczenia inhibitorem ACE lub ARB w dobowej dawce ekwiwalentnej do 2 razy $10 \mathrm{mg}$ enalaprilu [2]. Szczegółowe dane na temat ekwiwalentnych dawek inhibitora ACE i ARB do $10 \mathrm{mg}$ enalaprilu stosowanych przed zmianą leczenia na Entresto ${ }^{\mathrm{TM}}$ zaprezentowano $^{2}$ w tabeli 2 [9].

Warto przypomnieć, że w wytycznych ESC [2] zdefiniowano stabilność obrazu klinicznego w HF jako okres 4 tygodni bez zaostrzenia objawów HF, przy zachowaniu stałych dawek standardowej terapii (inhibitor ACE, beta-adrenolityk i MRA) - SoC (the standard of care).

Ponadto ESC przyznało klasę I i poziom dowodów A zaleceniu stosowania beta-adrenolityków, MRA i sakubitrylu/walsartanu u pacjentów z HFrEF oraz z komorowymi zaburzeniami rytmu serca $w$ celu obniżenia ryzyka nagłego zgonu sercowego [2]. Ponad $80 \%$ zgonów w badaniu PARADIGM-HF miało przyczynę sercowo-naczyniową [7, 10]. Obniżenie o 20\% ryzyka zgonów sercowo-naczyniowych w przypadku stosowania LCZ696 w porównaniu z enalaprilem wynikało głównie ze zmniejszenia częstości występowania nagłej śmierci sercowej o 20\% (LCZ696 v. enalapril: współczynnik ryzyka [HR, hazard ratio] 0,80, 95-proc. przedział ufności [Cl, confidence interval] 0,68-0,94; $p=0,008)$ i zgonu z powodu postępującej HF o $21 \%$ (LCZ696 v. enalapril: $\mathrm{HR}=0,79,95 \% \mathrm{Cl} 0,64-0,98 ; p=$ $=0,034)[10]$. Dane te wskazują, że największe korzyści podczas leczenia sakubitrylem/walsartanem w odniesieniu do
Tabela 2. Minimalne wymagane dawki inhibitora konwertazy angiotensyny (ACE, angiotensin-converting enzyme) i antagonisty receptora dla angiotensyny II (ARB, angiotensin receptor blocker) niezbędne do rozpoczęcia terapii preparatem Entresto ${ }^{T M}$ (źródło [9])

\begin{tabular}{lclc}
\multicolumn{2}{c}{ Inhibitor ACE } & \multicolumn{2}{c}{ ARB } \\
Nazwa leku & $\begin{array}{c}\text { Minimalna } \\
\text { dawka dobowa } \\
{[\mathrm{mg}]}\end{array}$ & Nazwa leku & $\begin{array}{c}\text { Minimalna } \\
\text { dawka dobowa } \\
{[\mathrm{mg}]}\end{array}$ \\
\hline Enalapril & 10 & Kandesartan & 16 \\
Kaptopril & 100 & Eprosartan & 400 \\
Cilazapril & 2,5 & Irbesartan & 150 \\
Fosinopril & 20 & Losartan & 50 \\
Lisinopril & 10 & Olmesartan & 10 \\
Moeksipril & 7,5 & Telmisartan & 40 \\
Perindopril & 4 & Walsartan & 160 \\
Kwinapril & 20 & & \\
Ramipril & 5 & & \\
Trandolapril & 2 & & \\
Zofenopril & 30 & & \\
& & & \\
& & & \\
& & & \\
\hline
\end{tabular}

śmiertelności uzyskają pacjenci zagrożeni nagłą śmiercią sercową i zgonem z powodu progresji HF, mimo optymalnej farmakoterapii. 
Tabela 3. Farmakoterapia stosowana przed rozpoczęciem leczenia preparatem Entresto ${ }^{\mathrm{TM}} \mathrm{u}$ obu opisanych pacjentów

\begin{tabular}{|c|c|}
\hline Pacjent 1. & Pacjent 2. \\
\hline Walsartan 160 mg: 0-0-1 tabl. (kaszel po inhibitorze ACE) & Ramipril 5 mg: 1-0-1 tabl. \\
\hline Karwedilol 25 mg: 2 × 1 tabl. & Bisoprolol 2,5 mg: 1 tabl. rano \\
\hline Eplerenon 50 mg: 1 tabl. w południe & Eplerenon 25 mg: 1 tabl. rano \\
\hline ASA 75 mg: 1 tabl. wieczorem & Riwaroksaban 20 mg: 1 tabl. rano \\
\hline Klopidogrel 75 mg: 1 tabl. rano & Cordarone $200 \mathrm{mg:} 1$ tabl. rano \\
\hline \multicolumn{2}{|l|}{ Atorwastatyna $40 \mathrm{mg:} 1$ tabl. wieczorem } \\
\hline Metformina $850 \mathrm{mg}: 3 \times 1$ tabl. & \\
\hline
\end{tabular}

Nowa grupa leków ARNI jest przełomem w leczeniu chorych z przewlekłą stabilną HFrEF. Poza nowymi możliwościami terapii lek sakubitryl/walsartan zmienia horyzonty poprawy rokowania w tej jednostce chorobowej i daje klinicystom nowe spojrzenie na populację chorych z HFrEF. W związku z tym nadszedł czas, aby ponownie zdefiniować optymalne leczenie w tej grupie chorych [11].

\section{Cel publikacji}

Celem publikacji było przedstawienie przypadków klinicznych 2 pacjentów z HFrEF, u których zainicjowano terapię lekiem sakubitryl/walsartan (preparat Entresto ${ }^{T M}$ ). W pracy zawarto praktyczne wskazówki dotyczące pierwszych doświadczeń klinicznych z nowym lekiem, w tym identyfikacji pacjentów mogących odnieść korzyści z modyfikacji dotychczasowego leczenia HFrEF.

\section{Opisy przypadków}

\section{Przypadek 1.}

U 62-letniego mężczyzny, aktywnego zawodowo pracownika umysłowego, występowała stabilna klinicznie przewlekła HF o etiologii niedokrwiennej, z utrzymującymi się objawami II-III klasy według NYHA oraz obrzękami kończyn dolnych wokół kostek. W badaniu echokardiograficznym (ECHO) opisywano dysfunkcję skurczową lewej komory (LVEF = $=26 \%$ ). Chory przebył zawał serca bez uniesienia odcinka ST (NSTEMI, non-ST-elevation myocardial infarction) i był leczony angioplastyką gałęzi zstępującej z implantacją stentu uwalniającego lek (DES, drug-eluting stent) (7.01.2016 r.) oraz angioplastyką gałęzi marginalnej z implantacją DES (6.04.2016 r.). Po konsultacji hemodynamicznej zakwalifikowano go do dalszego leczenia zachowawczego choroby wieńcowej. Dodatkowo chory jest obciążony cukrzycą typu 2 (przyjmował leki doustne), hiperlipidemią oraz nadciśnieniem tętniczym, aktualnie kontrolowanym - średnie wartości w pomiarach domowych wynosiły 125-135/80 mm Hg. Pacjent otrzymał zalecenia niefarmakologiczne dla chorych na HF oraz skierowanie do elektrofizjologa w celu oceny wskazań do elektroterapii po 3 miesiącach optymalnej farmakoterapii HF.

U pacjenta objawy nadal występowały mimo optymalnego leczenia farmakologicznego HF za pomocą ARB (kaszel po inhibitorze ACE), beta-adrenolityku i MRA od 2 miesięcy (tab. 3). Zgodnie z obowiązującymi wytycznymi ESC [2] chory spełniał kryteria włączenia ARNI. W tabeli 4 przedstawiono wybrane parametry i wyniki badań laboratoryjnych określające stan kliniczny pacjenta przed włączeniem preparatu Entresto ${ }^{T M}$.

Po miesiącu terapii preparatem Entresto ${ }^{T M}$, w dawce 49/51 mg 2 razy/dobe, uzyskano istotne zmniejszenie objawów HF (do I/II klasy wg NYHA), znaczne obniżenie stężenia $\mathrm{N}$-końcowego fragmentu propeptydu natriuretycznego typu B (NT-proBNP, N-terminal B-type natriuretic propetide), lepszą tolerancję wysiłku oraz ustąpienie obrzęków. Zaobserwowano niewielki, nieistotny klinicznie, wzrost stężenia potasu w surowicy, bez istotnych zmian funkcji nerek oraz w zakresie wartości skurczowego ciśnienia tętniczego (tab. 4). Zgodnie ze schematem dawkowania zawartym w Charakterystyce Produktu Leczniczego (ChPL) [5] dawkowanie leku sakubitryl/walsartan zwiększono do dawki docelowej, tj. 2 razy 97/103 mg.

Pacjent pozostaje pod dalszą obserwacją kliniczną, jest w I klasie niewydolności według NYHA, aktywny zawodowo, bez istotnych zmian parametrów skurczowego ciśnienia tętniczego, funkcji nerek i stężenia potasu. Oczekuje na konsultację elektrofizjologa; zalecono kontynuację dotychczasowej terapii.

\section{Przypadek 2.}

Mężczyzna w wieku 58 lat, pracownik umysłowy, był aktywny zawodowo do czasu rozpoznania kardiomiopatii rozstrzeniowej przed 3 miesiącami (wówczas HF de novo, III/IV klasa wg NYHA), obecnie z obrazem stabilnej klinicznie przewlekłej HF z utrzymującymi się objawami II klasy według NYHA. W badaniu ECHO stwierdzono obraz pierwotnej kardiomiopatii rozstrzeniowej z ciężką dysfunkcją skurczową - LVEF równa 18\%. Dodatkowo chorego obciążają nadciś- 
Tabela 4. Wybrane wyniki badań laboratoryjnych i parametrów przed terapią sakubitrylem/walsartanem i w jej trakcie u obu opisanych pacjentów

\begin{tabular}{|c|c|c|c|c|}
\hline \multirow[t]{2}{*}{ Wybrane parametry } & \multicolumn{2}{|c|}{ Pacjent 1.} & \multicolumn{2}{|c|}{ Pacjent 2.} \\
\hline & $\begin{array}{c}\text { Wyjściowo przed } \\
\text { włączeniem terapii }\end{array}$ & $\begin{array}{l}\text { Po miesiącu terapii S/W } \\
2 \times 49 / 51 \mathrm{mg}\end{array}$ & $\begin{array}{l}\text { Wyjściowo przed } \\
\text { włączeniem terapii }\end{array}$ & $\begin{array}{l}\text { Po miesiącu terapii S/W } \\
2 \times 49 / 51 \mathrm{mg}\end{array}$ \\
\hline Klasa wg NYHA & III & I/II & ॥ & Bezobjawowy \\
\hline $\begin{array}{l}\text { Ciśnienie tętnicze } \\
{[\mathrm{mm} \mathrm{Hg}]}\end{array}$ & $125 / 80$ & $120 / 80$ & $110 / 75$ & $125 / 80$ \\
\hline Dystans w 6MWT [m] & 300 & Bez ograniczeń & 447 & Bez ograniczeń \\
\hline $\begin{array}{l}\text { Obrzęki w okolicy } \\
\text { kostek }\end{array}$ & + & - & - & - \\
\hline $\begin{array}{l}\text { Stężenie NT-proBNP } \\
{[\mathrm{pg} / \mathrm{ml}]}\end{array}$ & 1595 & 678 & 1976 & 437 \\
\hline $\begin{array}{l}\text { Wartość eGFR } \\
{\left[\mathrm{ml} / \mathrm{min} / 1,73 \mathrm{~m}^{2}\right]}\end{array}$ & 101 & 99 & 58 & 79 \\
\hline $\begin{array}{l}\text { Stężenie potasu }\left(\mathrm{K}^{+}\right) \\
{[\mathrm{mmol} / \mathrm{l}]}\end{array}$ & 4,2 & 4,7 & 4,57 & 4,6 \\
\hline
\end{tabular}

S/W - sakubitryl/walsartan; NYHA - New York Heart Association; 6MWT (6-minute walk test) - test 6-minutowego marszu; NT-proBNP (N-terminal B-type natriuretic propetide) - N-końcowy fragment propeptydu natriuretycznego typu B; eGFR (estimated glomerular filtration rate) - szacowany współczynnik przesączania kłębuszkowego

nienie tętnicze, obecnie kontrolowane (średnie wartości w pomiarach domowych 110/75 mm Hg), oraz migotanie przedsionków po skutecznej kardiowersji elektrycznej w grudniu 2016 roku. U pacjenta nadal występowały objawy mimo optymalnego leczenia farmakologicznego HF inhibitorem ACE, beta-adrenolitykiem i MRA od 6 tygodni (tab. 3). W tabeli 4 przedstawiono wybrane parametry i wyniki badań laboratoryjnych określające stan kliniczny pacjenta przed włączeniem preparatu Entresto ${ }^{T M}$.

Zgodnie z obowiązującymi wytycznymi [2] chory spełniał kryteria wdrożenia ARNI. Preparat Entresto ${ }^{\text {TM }}$ włączono dawce 49/51 mg 2 razy/dobe, po 36 godzinach przerwy od ostatniej dawki ramiprilu, nie zmieniając pozostałej farmakoterapii. Utrzymano zalecenia niefarmakologiczne dla chorych na HF.

Po miesiącu terapii preparatem Entresto ${ }^{\mathrm{TM}}$, w dawce 2 razy 49/51 mg, uzyskano zmniejszenie objawów HF, znaczne obniżenie stężenia NT-proBNP oraz lepszą tolerancję wysiłku oraz wartości ciśnienia tętniczego (tab. 4). Ponadto obserwowano poprawę funkcji nerek, bez istotnych zmian stężenia potasu w surowicy krwi oraz wartości ciśnienia tętniczego (tab. 4). Dawkowanie leku sakubitryl/ /walsartan zwiększono do 2 razy 97/103 mg.

Pacjent pozostaje pod dalszą obserwacją kliniczną, powrócił do aktywności zawodowych, bez istotnych zmian parametrów skurczowego ciśnienia tętniczego, funkcji nerek i stężenia potasu. Kontrolne stężenie NT-proBNP po miesiącu terapii docelową dawką terapeutyczną wyniosło 78 pg/ml, a LVEF w kontrolnej ocenie echokardiograficznej osiągnęła 30\%. Chory oczekuje na konsultację elektrofizjologa; zalecono kontynuację dotychczasowej terapii.

\section{Omówienie}

Jak zainicjować i optymalizować leczenie sakubitrylem/walsartanem

Zgodnie z CHPL nie należy włączać leczenia preparatem Entresto $^{\mathrm{TM}}$ wcześniej niż po 36 godzinach od przyjęcia przez chorego ostatniej dawki inhibitora ACE, ze względu na możliwe ryzyko obrzęku naczynioruchowego. Do momentu włączenia pierwszej dawki Entresto ${ }^{\mathrm{TM}}$ chory może bezpiecznie pozostawać bez inhibitora ACE przez 36 godzin. Zaprzestanie stosowania inhibitora ACE nie wymaga nadzoru lekarza [5].

W przypadku wcześniejszego stosowania ARB nie jest wymagana przerwa w leczeniu sartanami. Sakubitryl/ /walsartan może zostać włączony kolejnego dnia w miejsce ARB [5]. Według ChPL [5] zalecana dawka początkowa Entresto $^{\mathrm{TM}}$ to jedna tabletka $49 / 51 \mathrm{mg}$ podawana 2 razy/ /dobę, jeśli skurczowe ciśnienie tętnicze osiąga co najmniej 110 mm Hg. Po 2-4 tygodniach przy dobrej tolerancji leku dawkę należy podwoić do dawki docelowej, czyli jednej tabletki 97/103 mg podawanej 2 razy/dobę. Przed każdym zwiększeniem dawki konieczne jest sprawdzenie stężenia potasu i parametrów nerkowych.

Do najczęściej występujących objawów niepożądanych związanych ze stosowaniem leku sakubitryl/walsartan zalicza się [5]:

- obniżenie skurczowego ciśnienia tętniczego poniżej $95 \mathrm{~mm} \mathrm{Hg}$;

- objawy niedociśnienia;

- hiperkaliemię ze stężeniem $\mathrm{K}^{+}$ponad 5,4 mmol/l;

- zaburzenia czynności nerek. 


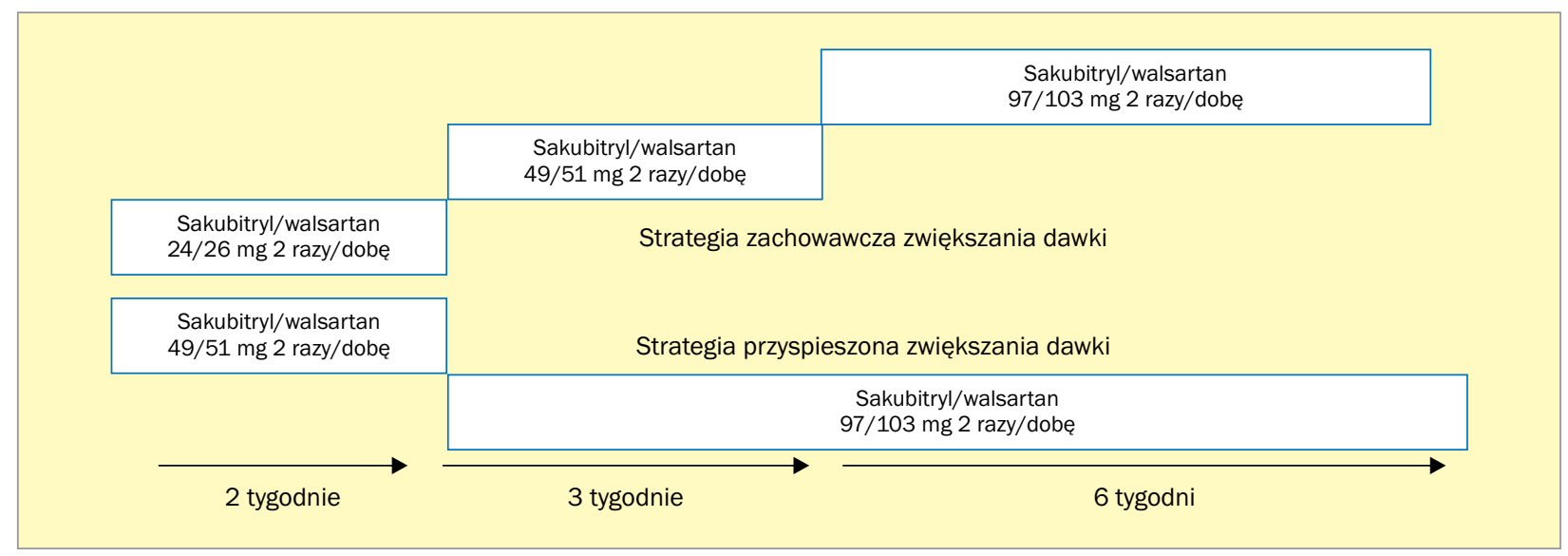

Rycina 2. Schemat dawkowania leku sakubitryl/walsartan według badania TITRATION (Safety and Tolerability of Initiating LCZ696 in Heart Failure Patients) (zmodyfikowane przez autorów na podstawie [12])

W sytuacji wystąpienia objawów niepożądanych zaleca się redukcję dawkowania jednocześnie podawanych leków o działaniu hipotensyjnym i czasowe zmniejszenie dawki preparatu Entresto TM lub przerwanie podawania leku $[5,8]$.

W badaniu TITRATION (Safety and Tolerability of Initiating LCZ696 in Heart Failure Patients) przedstawiono dwie możliwe strategie optymalizacji dawkowania leku sakubitryl/walsartan (ryc. 2) [12] - zachowawczą, ze stopniowym zwiększaniem dawki od 49/51 do 97/103 mg w czasie 6 tygodni, oraz przyspieszoną, zgodnie z którą dawka jest zwiększana w ciągu 3 tygodni.

Schemat zachowawczy optymalizacji dawkowania jest rekomendowany jako bezpieczniejszy dla pacjentów dotychczas leczonych małymi dawkami inhibitora ACE/ARB odpowiadającymi dawce nie większej niż $10 \mathrm{mg}$ enalaprilu/dobę lub dawce nie większej niż $160 \mathrm{mg}$ walsartanu/ /dobę, dla pacjentów starszych, a także z umiarkowanymi zaburzeniami czynności wątroby (stopień B w skali Child-Pugh). U pacjentów uprzednio leczonych średnimi/dużymi dawkami inhibitora ACE/ARB, tj. ponad $10 \mathrm{mg}$ enalaprilu lub więcej niż $160 \mathrm{mg}$ walsartanu, lub równoważną terapeutycznie dawką innego inhibitora ACE lub ARB, zaleca się intensywniejsze zwiększanie dawkowania preparatu Entresto $^{T M}$ według strategii przyspieszonej [12].

W leczeniu preparatem Entresto ${ }^{\mathrm{TM}}$ należy dążyć do dawki maksymalnej 97/103 mg 2 razy/dobę [5, 8]. Przykładowy algorytm włączania i prowadzenia terapii tym preparatem przedstawiono na rycinie 3.

\section{Wskazówki praktyczne}

Jako substrat neprylizyny BNP nie jest właściwym biomarkerem HF u pacjentów leczonych lekiem sakubitryl/walsartan. Wartość NT-proBNP pozwala ocenić efekt terapeutyczny pod postacią obniżenia stężenia peptydu natriuretycznego $[5,11]$. Ponadto nie należy rozpoczynać leczenia lekiem sakubitryl/walsartan u pacjentów ze skurczowym ciśnieniem tętniczym poniżej $100 \mathrm{~mm} \mathrm{Hg} \mathrm{[5].}$

Zgodnie z ChPL [5] rozpoczęcie leczenia od najmniejszej dawki Entresto ${ }^{T M}$, tj. 24/26 mg 2 razy/dobę, jest zarezerwowane dla szczególnych grup:

- pacjentów, którzy nie stosowali wcześniej inhibitora ACE lub ARB;

- pacjentów, którzy stosują małą dzienną dawkę enalaprilu nie większą niż 10 mg lub walsartanu nieprzekraczającą 160 mg, lub równoważną terapeutycznie dawkę innego inhibitora ACE czy ARB;

- pacjentów z wartościami skurczowego ciśnienia tętniczego 100-110 mm Hg;

- pacjentów z ciężka niewydolnością nerek (szacowany współczynnik przesączania kłębuszkowego [eGFR (estimated glomerular filtration rate] $<30 \mathrm{ml} / \mathrm{min} / 1,73 \mathrm{~m}^{2}$ );

- pacjentów z umiarkowaną niewydolnością wątroby (klasa B wg skali Childa-Pugha);

według zasady podwojenia dawki po 2-4 tygodniach w zależności od tolerancji leku oraz wyników badań eGFR i stężenia potasu w surowicy krwi.

\section{Przeciwwskazania do stosowania leku sakubitryl/walsartan}

Zgodnie z ChPL [5] stosowanie preparatu Entresto ${ }^{\text {TM }}$ jest przeciwwskazane u następujących pacjentów:

- z obrzękiem naczynioruchowym w wywiadzie związanym z wcześniejszym leczeniem inhibitorem ACE lub ARB;

- z dziedzicznym lub idiopatycznym obrzękiem naczynioruchowym;

- z hiperkaliemią ponad 5,4 mmol/l, ponieważ stosowanie leku może powodować wzrost stężenia potasu we krwi;

- z ciężkimi zaburzeniami czynności wątroby, marskością żółciową i cholestazą (stopień C wg skali Child-Pugh);

- ze schyłkową niewydolnością nerek; 
Ambulatoryjny pacjent z HFrEF

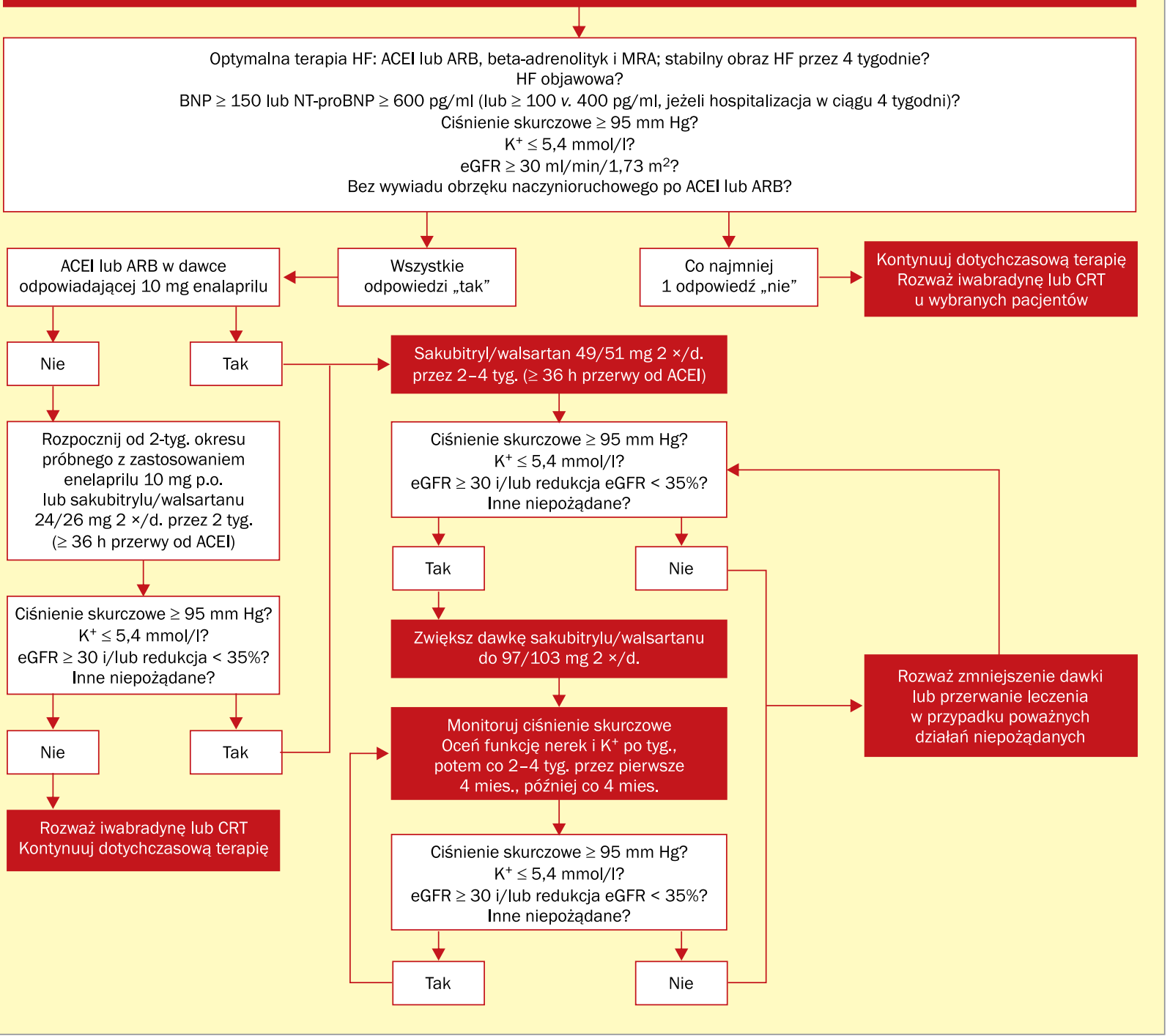

Rycina 3. Proponowany algorytm włączania do terapii niewydolności serca (HF, heart failure) sakubitrylu/walsartanu w codziennej praktyce klinicznej (zmodyfikowane przez autorów na podstawie [8]); HFrEF (heart failure reduced ejection fraction) - niewydolność serca z obniżoną frakcją wyrzutową; ACEI (angiotensin-converting enzyme inhibitor) - inhibitor konwertazy angiotensyny; ARB (angiotensin receptor blocker) - antagonista receptora dla angiotensyny II; MRA (mineralocorticoid receptor antagonist) - antagonista receptora mineralokortykoidowego; BNP (B-type natriuretic propetide) - peptyd natriuretyczny typu B; NT-proBNP (N-terminal B-type natriuretic propetide) - N-końcowy fragment propeptydu natriuretycznego typu B; eGFR (estimated glomerular filtration rate) - szacunkowy współczynnik filtracji kłębuszkowej; CRT (cardiac resynchronization therapy) - terapia resynchronizująca; p.o. (per os) - doustnie

- kobiet w II lub III trymestrze ciąży;

- z nadwrażliwością na substancje czynne lub którąkolwiek substancje pomocniczą;

- przyjmujących inny produkt leczniczy zawierający ARB - ze względu na zawartość walsartanu w preparacie Entresto ${ }^{T M}$ jednoczesne stosowanie jest przeciwwskazanie;

- przyjmujących inhibitor ACE - przeciwwskazane jest jednoczesne stosowanie preparatu Entresto ${ }^{T M}$;

- u chorych na cukrzycę i/lub z zaburzeniami czynności nerek (eGFR $<60 \mathrm{ml} / \mathrm{min} / 1,73 \mathrm{~m}^{2}$ ) przyjmujących bez- pośrednie inhibitory reniny, takie jak aliskiren - przeciwwskazane jest jednoczesne stosowanie preparatu Entresto $^{T M}[5]$.

\section{Podsumowanie}

Opisani pacjenci są dobrym przykładem bezpiecznej terapii nową grupą leków ARNI - jej przedstawicielem, lekiem sakubitryl/walsartan. Lek ten został włączony zgodnie z ChPL oraz profilem klinicznym pacjenta z badania 
PARADIGM-HF. Dla pierwszych doświadczeń związanych z wprowadzaniem leku sakubitryl/walsartan kluczowa jest właściwa identyfikacja pacjenta. Wyselekcjonowani objawowi chorzy powinni się cechować stabilnym obrazem przewlekłej HFrEF oraz stosować leczenie SoC z dobrą tolerancją inhibitorów ACE lub ARB, nie wykazywać ciężkiego upośledzenia funkcji nerek ani stężenia potasu w surowicy krwi powyżej 5,4 mmol/l. W drugim etapie leczenia lekiem sakubitryl/walsartan celem powinna być optymalizacja terapii z dążeniem do docelowych dawek rekomendowanych wynoszących 97/103 mg podawanych 2 razy/dobę.

\section{Konflikt interesów}

Autorki uczestniczą w badaniach PARAGON-HF i TRANSITION.

\section{Abstract}

The European Society of Cardiology (ESC) introduced a new class of drugs - ARNI (angiotensin receptor-neprilysin inhibitor) in patients with heart failure and reduced ejection fraction (HFrEF) (class I, level of evidence B) in the recently published guidelines for heart failure (HF), published in 2016. The only representative of ARNI is sacubitril/valsartan. Based on the results of the PARADAGIM-HF study, sacubitril/valsartan is recommended instead of angiotensin-converting enzyme inhibitors (ACEI) to further reduce the risk of death and hospitalization because of HF in outpatients with stable HFrEF, with symptomatic HF (NYHA II-IV) persist despite optimal treatment with ACEI (or angiotensin II receptor antagonists), beta-adrenolytic and mineralocorticoid receptor antagonist. The paper presents case report of first 2 patients with HFrEF who sacubitril/valsartan therapy was initiated.

Key words: heart failure, angiotensyn II receptor antagonist and neprilysin inhibitor, ARNI

Folia Cardiologica 2017; 12, 4: 397-404

\section{Piśmiennictwo}

1. Niewydolność serca w Polsce - raport 2016. Materiały informacyjne Sekcji Niewydolności Serca PTK. http://www.niewydolnosc-serca.pl/ /barometr.pdf (9.05.2017).

2. Ponikowski P, Voors AA, Anker SD. ESC guidelines for the diagnosis and treatment of acute and chronic heart failure 2012: the Task Force for the Diagnosis and Treatment of Acute and Chronic Heart Failure 2012 of the European Society of Cardiology. Developed in collaboration with the Heart Failure Association (HFA) of the ESC. Eur Heart J. 2016; 37(27): 2129-2200, doi: doi: 10.1093/eurheartj/ehw128, indexed in Pubmed: 27206819.

3. Sobczak S, Lelonek M. LCZ696 przełomem w leczeniu przewlekłej niewydolności serca z obniżoną frakcją wyrzutową lewej komory. Folia Cardiol. 2016; 10(6): 403-409, doi: 10.5603/fc.2015.0077.

4. Lelonek M. Niewydolność serca i powtarzające się hospitalizacje. Folia Cardiol. 2016; 11(1): 37-46, doi: 10.5603/fc.2016.0005.

5. Entresto ${ }^{\mathrm{TM}}$. Charakterystyka Produktu Leczniczego 2015.

6. Hussar DA, Abdelsayed M. Sacubitril/valsartan, ivabradine hydrochloride, alirocumab, and evolocumab. J Am Pharm Assoc. 2015; 55(6): 674-678, doi: 10.1331/JAPhA.2015.15551, indexed in Pubmed: 26547602.

7. McMurray JJV, Packer M, Desai AS, et al. PARADIGM-HF Investigators and Committees. Angiotensin-neprilysin inhibition versus enalapril in heart failure. N Engl J Med. 2014; 371(11): 993-1004, doi: 10.1056/ /NEJMoa1409077, indexed in Pubmed: 25176015.
8. Farmakis D, Bistola V, Karavidas A, et al. Practical considerations on the introduction of sacubitril/valsartan in clinical practice: current evidence and early experience. Int J Cardiol. 2016; 223: 781-784, doi: 10.1016/j.ijcard.2016.08.323, indexed in Pubmed: 27573608.

9. McMurray JJV, Packer M, Desai AS, et al. PARADIGM-HF Committees and Investigators. Dual angiotensin receptor and neprilysin inhibition as an alternative to angiotensin-converting enzyme inhibition in patients with chronic systolic heart failure: rationale for and design of the Prospective comparison of ARNI with ACEI to Determine Impact on Global Mortality and morbidity in Heart Failure trial (PARADIGM-HF). Eur J Heart Fail. 2013; 15(9): 1062-1073, doi: 10.1093/eurjhf/ /hft052, indexed in Pubmed: 23563576.

10. Desai AS, McMurray JJV, Packer M, et al. Effect of the angiotensin-receptor-neprilysin inhibitor LCZ696 compared with enalapril on mode of death in heart failure patients. Eur Heart J. 2015; 36(30): 1990-1997, doi: 10.1093/eurheartj/ehv186, indexed in Pubmed: 26022006.

11. Lelonek $\mathrm{M}$. The need to apply the best therapy in heart failure the era after PARADIGM-HF. Arch Med Sci. https://www.termedia.pl/ /The-need-to-apply-the-best-therapy-in-heart-failure-the-era-after-PARADIGM-HF,19,27495,1,1.html (9.05.2017).

12. Senni M, McMurray JJV, Wachter R, et al. Initiating sacubitril/valsar$\tan$ (LCZ696) in heart failure: results of TITRATION, a double-blind, randomized comparison of two uptitration regimens. Eur J Heart Fail. 2016; 18(9): 1193-1202, doi: 10.1002/ejhf.548, indexed in Pubmed: 27170530. 